\title{
COMPUTER SUPPORTED EDUCATION - RESULTS OF RESEARCH PROBE
}

\section{Jiř́ DOSTÁL - Milan KLEMENT}

\begin{abstract}
This paper presents results of the research realized on the schools in the Czech Republic. It focuses on the findings of fact, how often teachers use a computer and the internet. It was found that teachers use a computer and the internet to prepare to instruction, to communicate with pupils and parents, to further self-education and directly in instruction.
\end{abstract}

Key words: computer based instruction, e-learning, ICT, research, education.

\section{POČÍTAČEM PODPOROVANÉ VZDĚLÁVÁNÍ - VÝSLEDKY VÝZKUMNÉ SONDY}

Resumé: Článek prezentuje výsledky výzkumného šetření realizovaného na školách v České republice. Zaměřuje se na zjištění skutečnosti, v jaké míře využívají učitelé počítač a internet. Bylo zjištěno, že učitelé využívají počítač a internet $\mathrm{k}$ př́ípravě na výuku, ke komunikaci s žáky a rodiči, k dalšímu sebevzdělávání a př́imo ve výuce.

Klíčová slova: počítačem podporovaná výuka, e-learning, ICT, výzkum, vzdělávání.

\section{1 Úvod}

Tradiční model výuky je stále více ovlivňován využíváním moderních technologií, v poslední době zejména využíváním multimediálních a interaktivních objekti̊. Děje se tak např́č všemi vyučovacími předměty, jsou využívány jak při výuce př́rodopisu, zeměpisu, technické výchovy, tak i např. chemie, hudební nebo výtvarné výchovy. Integrace moderních technologií do výuky se nevyhýbá žádnému stupni vzdělávání (uplatnění nacházejí v mateřských školách, na prvním i druhém stupni základních škol, stejně tak jsou ale využívány i na středních a jiných školách), což je zřetelné i z řady publikací, napřr. J. GAGE (1), D. SQUIRES - A. MCDOUGALL (2), R. E. MAYER (3), L. J. NAJJAR (4), R. SUTHERLAND - K. FACER - R. FURLONG J. FURLONG (5), J. ROSCHELLE - $\mathrm{CH}$. DIGIANO - M. KOUTLIS, et all. (6), H. MAREŠOVÁ (7).

Současná teorie není schopná jednoznačně odpovědět na aktuální otázky s pojené s využíváním moderních informačních a komunikačních technologií, např. není zřejmé, v jaké míre jsou ICT využivány v běžných činnostech pedagoga či za jakým účelem jsou využívány didaktické počítačové programy.

\section{Použité výzkumné metody a charakteristika respondentů}

Výzkumné šetření bylo realizováno jako víceleté. $\mathrm{Na}$ základě prímého kontaktu se zkoumanou praxí, kdy probíhaly rozhovory a hospitace na školách, byl sestaven dotazník, který byl následně distribuován prostřednictvím tř́ kanálů - osobně, poštou a elektronicky s využitím on-line dotazníku.

Celkem se podařilo získat 281 úplně vyplněných dotazníků, které jsou postupně převáděny do tabulek za účelem statistické zpracování. Ke dni zpracování této stati bylo zpracováno 138 dotazníků, ostatní jsou dále digitalizovány.

Výzkumný vzorek zahrnoval učitele mateřských, základních a středních škol (kategorie „Jiné“ představuje speciální školy). Složení včetně procentuálního vyjádření je zřetelné z grafu č. 1 .

Z hlediska pohlaví se výzkumu účastnilo $23 \%$ mužŭ a 77 \% žen, což odráží normální složení pedagogických pracovníků v České republice. 


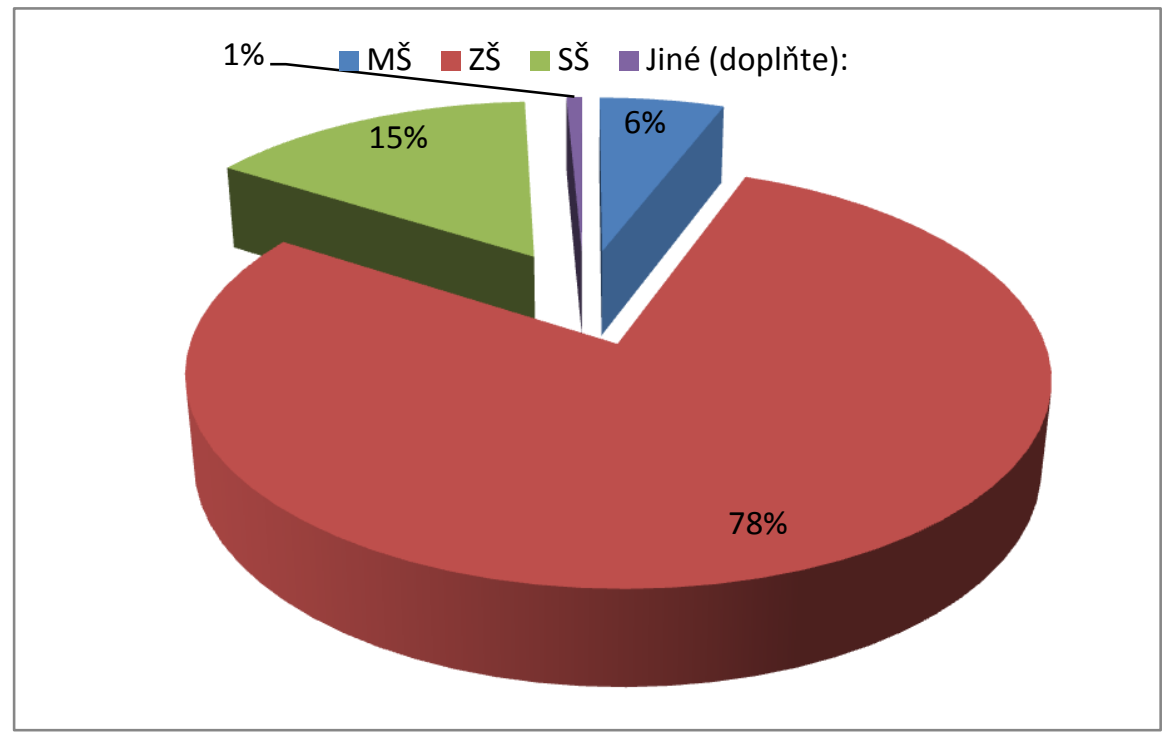

\section{Graf č. 1: Složení výzkumného vzorku - dle typu školy}

Učitelé, kteří se do výzkumu zapojili, vyučují z grafu č. 2. Výzkumný vzorek je složen z učitelů jednotlivé předměty $\mathrm{v}$ poměru, který je zretelelný celé řady aprobací.

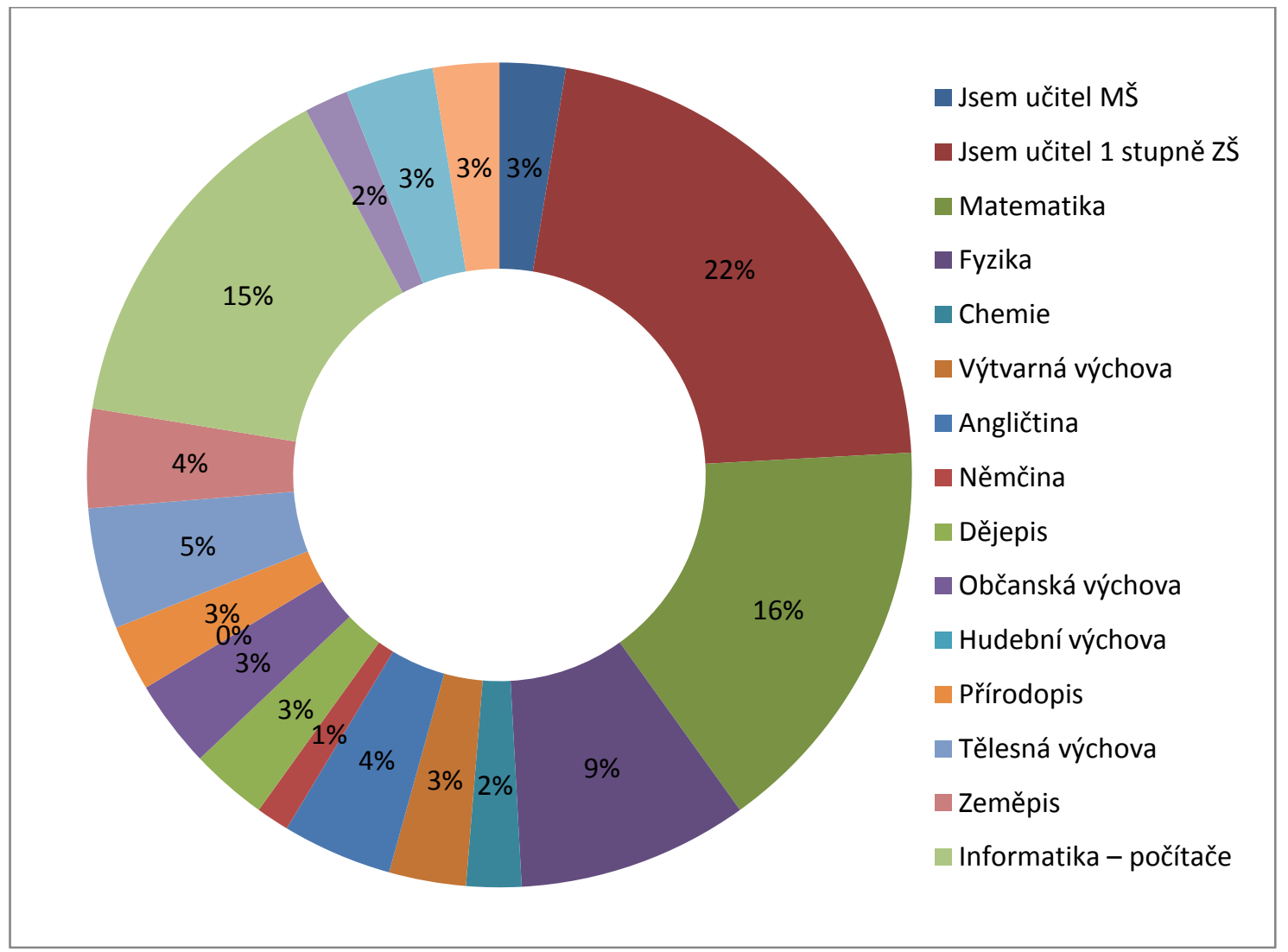

Graf č. 2: Složení výzkumného vzorku - dle vyučovaného předmětu

Následující graf zobrazuje složení města, kde sídlí škola, na níž pedagog vyplňující výzkumného vzorku z hlediska velikosti obce či dotazník působí. 


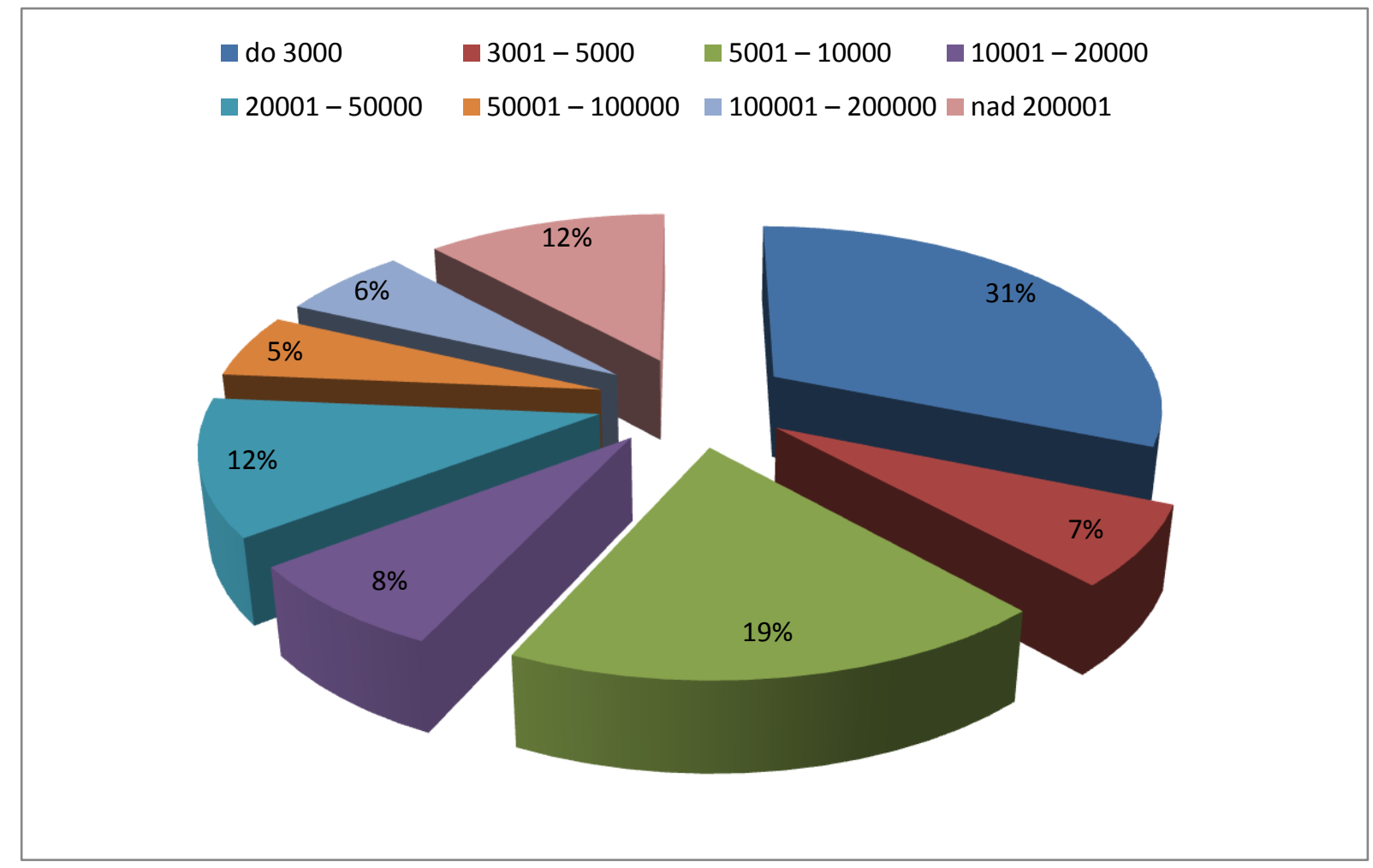

Graf č. 3: Složení výzkumného vzorku - dle velikosti obce či města, kde sídlí škola, na níž pedagog vyplňující dotazník působí

3 Forma využívání počítače pedagogickými pracovníky na českých školách

Využití počítače pedagogickými pracovníky může mít různé formy, $v$ současnosti však žádné výzkumy, které byly na území České republiky realizovány, nepodávají aktuální informaci o tom, v jaké míre a jak počítače učitelé využívají. Proto byla v rámci dotazníku zařazena otázka „Jakou formou využiváte počítač při Vaší práci (práci pedagoga)?“. Bylo možné označit více odpovědí.

Z následující tabulky a grafu je zretelné, že učitelé využívají počítače $\mathrm{v}$ největší míře $\mathrm{k}$ př́pravě na výuku. V nejmenší míře ho využívají ke komunikaci a rodiči.

Tabulka č. 1: Výsledky šetření - forma využívání počítače při práci pedagoga

\begin{tabular}{|c|c|c|c|c|c|}
\hline \multicolumn{6}{|c|}{ Jakou formou využíváte počítač při Vaší práci (práci pedagoga)? } \\
\hline & \begin{tabular}{|l}
\multicolumn{1}{|c}{$\mathrm{Ve}$} \\
lmi \\
často
\end{tabular} & $\begin{array}{r}\check{C} \\
\text { asto }\end{array}$ & $\begin{array}{r}\mathrm{O} \\
\text { bčas }\end{array}$ & $\begin{array}{c}\text { Spíše } \\
\text { nevyužívám }\end{array}$ & $\begin{array}{l}\text { Nevyuží } \\
\text { vám }\end{array}$ \\
\hline Příprava na výuku & 75 & $4^{3}$ & 22 & 10 & 3 \\
\hline Administrativa (evidence známek, studentů...) & 58 & $0^{3}$ & 27 & 17 & 11 \\
\hline Využití výukových prezentací & 33 & $2^{3}$ & 34 & 28 & 17 \\
\hline Použití výukových programů & 36 & $5^{3}$ & 36 & 23 & 14 \\
\hline Komunikace s žáky nebo rodiči & 15 & $3^{2}$ & 37 & 39 & 30 \\
\hline
\end{tabular}




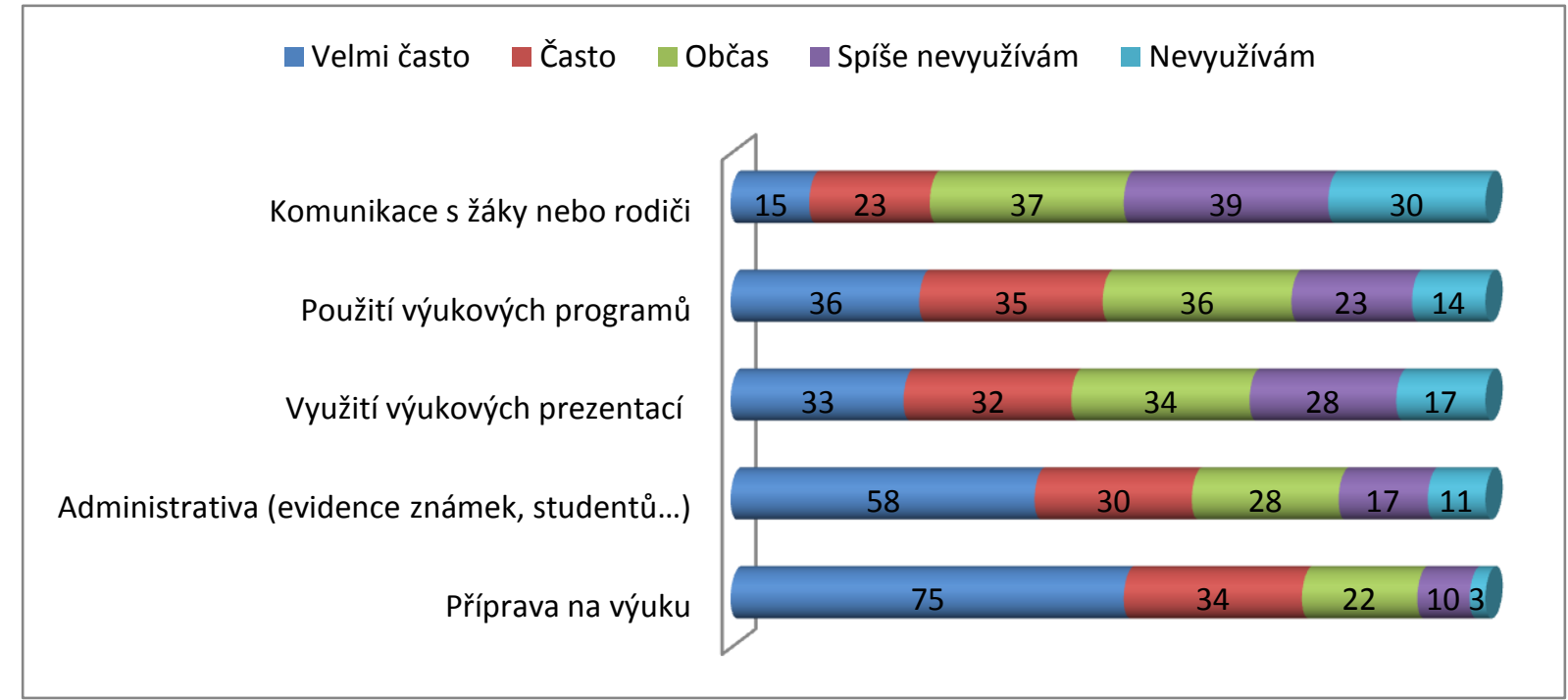

Graf č. 4: Výsledky šetření - forma využívání počítače při práci pedagoga

4 Forma využívání internetu v práci učitele na českých školách

Internet dnes ve vzdělávání zastává nezastupitelné místo, a proto se jevilo jako žádoucí zjistit, k jakým aktivitám je učiteli využíván. $\mathrm{Z}$ tohoto důvodu byla $\mathrm{v}$ dotazníku zahrnuta otázka „Jakým způsobem využíváte internet?“.

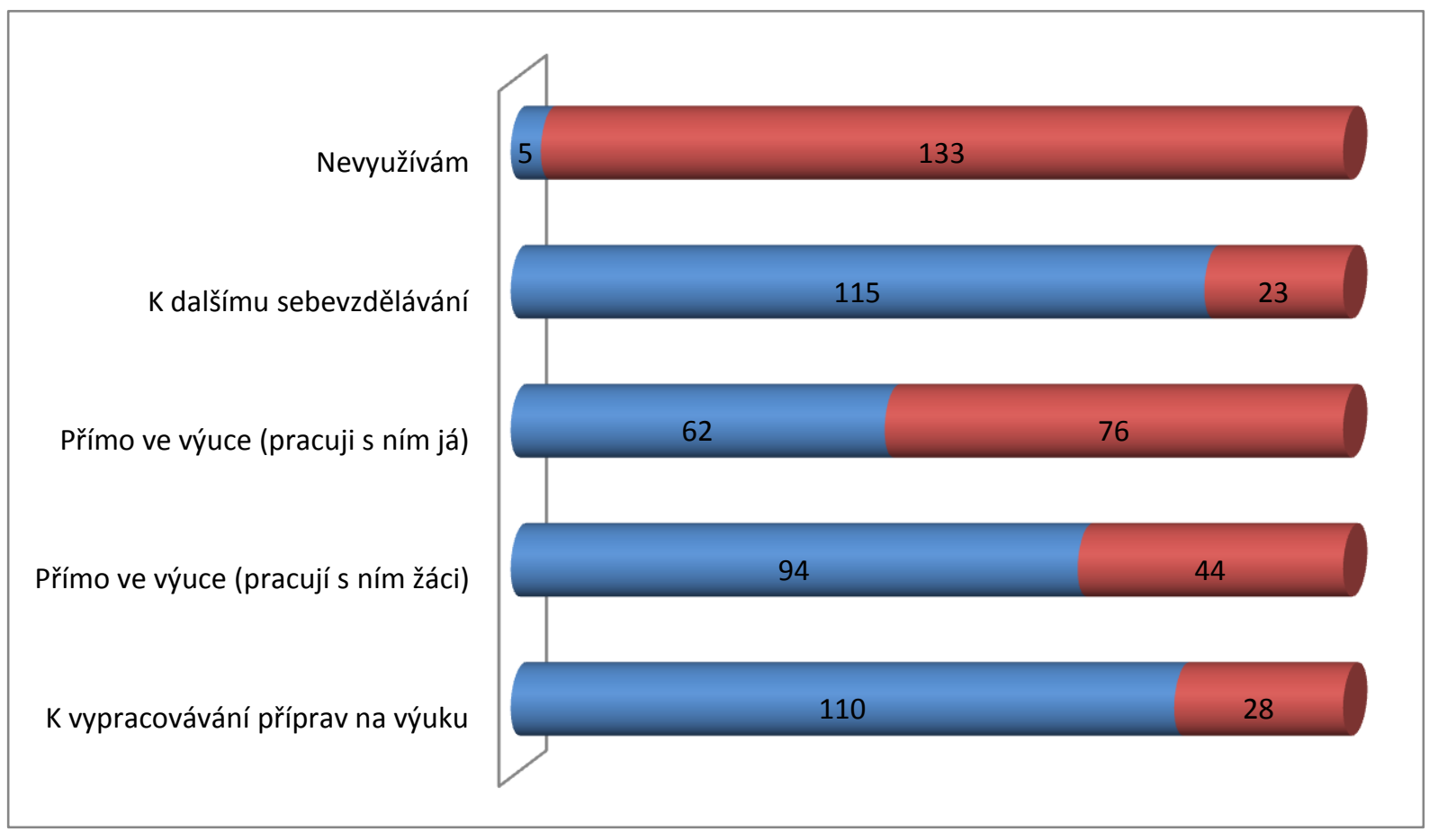

Graf č. 5: Výsledky šetření - forma využívání internetu v práci učitele

Z grafu je jednoznačně zřetelné, že převážná většina (přesně 96 \%) pedagogických pracovníků využívá internet. Pokud budeme analyzovat, jakým způsobem je využíván, zjistíme, že ve většině případů $\mathrm{k}$ dalšímu sebevzdělávání a k vypracovávání príprav na výuku (cca 80 \%). $\mathrm{V}$ o něco menší míře je internet využíván prrímo ve výuce, což je velmi pozitivní. Žáci se tak učí 
smysluplně využívat internet a pracovat s informacemi. Internet je ve větší míře využíván žáky, což stimuluje jejich aktivitu ve výuce a eliminuje pasivní př́ijem informací.

\section{Závěr}

V rámci stati byly prezentovány dílčí závěry výzkumného šetření realizovaného na českých školách. Již nyní, kdy je zpracována pouze část odpovědí respondentů, se jednoznačně prokazuje, že využívání moderních technologií je přirozenou součástí vzdělávání na českých školách. Bylo zjištěno, že počítač představuje rozhodující roli nejen při prŕpravě výuky, ale i ve výuce samotné.

$\mathrm{V}$ další etapě bude probíhat digitalizace naměřených dat, jejich tř́iění, vyhodnocování a hledání vzájemných souvislostí.

\section{Literatura}

[1] GAGE, J. How to use an interactive whiteboard really effectively in your secondary classroom. London: David Fulton Publis, 2006. 139 pages. ISBN 978-1-84312-262-3.

[2] SQUIRES, D. - MCDOUGALL, A. Choosing And Using Educational Software. London: Routledge 2002. 144 s. ISBN 0-75070306-7.

[3] MAYER, R. E. Multi-media learning. Cambridge: Cambridge University Press. 2001. 210 p. ISBN 0-521-78749-1.

[4] NAJJAR, L. J. Multimedia Information and Learning. Journal of Educational Multimedia and Hypermedia. Volume 5, Number 2, 1996. p. 129 - 50. ISSN 1055-8896.
[5] SUTHERLAND, R. - FACER, K. FURLONG, R. - FURLONG, J. A new environment for education? The computer in the home. Computers \& Education. Volume 34, Issues 3 - 4, 1 April 2000, Pages 195 - 212. ISSN 0360-1315.

[6] ROSCHELlE, J. - DIGIANO, CH. KOUTLIS, M. et all. Developing Educational Software Components. Computer. vol. 32, no. 9, pp. 50 - 58, Sept., 1999. ISSN 0018-9162.

[7] MAREŠOVÁ, H. The Role of information and communication technologies in the Czech Language Education. In Johannes Amos Comenius. The Legacy to the Culture of Education. Praha: Academia, 2009, s. 723-730. ISBN 978-80-200-1700-0.

Lektoroval: Mgr. René Szotkowski, Ph.D.

Článek vznikl za podpory GAČR v rámci řešení projektu č. P407/11/1306 „Evaluace vzdělávacích materiálů určených pro distanční vzdělávání a e-learning““.

Jiří Dostál, PaedDr. PhDr. Ph.D.

Pedagogická fakulta UP

Žižkovo nám. 5, 77140 Olomouc, ČR

tel. 00420585635818 ,

e-mail j.dostal@upol.cz

Milan Klement, PhDr. Ph.D.

Pedagogická fakulta UP

Žižkovo nám. 5, 77140 Olomouc, ČR

tel. 00420585635811 ,

e-mail milan.klement@upol.cz 